\title{
CHANGE AT DISTANCE EDUCATION, WHAT KIND OF RESISTANCE? WHAT IMPROVEMENTS?
}

\author{
Dr. Carles DULSAT \\ ORCID: 0000-0003-1351-8506 \\ Faculty of Humanirties and Social Science \\ University Isabel I \\ Burgos, SPAIN \\ Dr. Isabel ALVAREZ \\ ORCID: 0000-0001-9488-9960 \\ Department of Social and Systematic Pedagogy \\ Autonomous University of Barcelona \\ Bellaterra, San Cugat del Valles, SPAIN
}

Received: 04/12/2019 Accepted: 21/02/2020

\begin{abstract}
The study is aimed at training sports technicians in the Spanish state. Currently, most of them are in transitory period. For research, the Theory of Resistance in Innovation has been considered. This theory proposes a functional dimension and a psychological dimension with five factors: (Use, value of the product and risks involved) and (elements associated with traditional beliefs and those related to the image). The context studied was the courses taken by the Royal Spanish Skating Federation. The methodology followed in this research is empirical-analytical with a non-experimental approach. It will be basically a descriptive investigation. For this, an ad-hoc instrument was constructed with quantitative and qualitative response items. Among the results, it is worth highlighting the significant differences existing in students with experience in distance learning in the variable of acceptance of new technologies. In the qualitative part, it is recognized that the online mode allows to apply the knowledge immediately although there are difficulties during the first weeks. The creation of the figure of a tutor is proposed, which will catalyze the introduction to students' courses, facilitating the use of the platform before the start of the course.
\end{abstract}

Keywords: e-learning, innovation, technicians training, platform, functional factors.

\section{INTRODUCTION}

Distance education is increasingly present and accepted within general and regulated education (Bozkurt, 2019). This acceptance and presence is evident in post-compulsory and university education. Compulsory education reinforces the teaching of new technologies. Aspects related to the use of teaching and learning platforms must be included. These post-compulsory teachings contain: special teaching, teaching of training cycles expanding the offer and expanding the possibilities of students to study high school in the Spanish state (Dulsat \& Alvarez, 2018). It cannot forgotten that, for continuous and ongoing training, there are MOOCs courses as referents of training in any professional field to expand knowledge or update them.

Callary et al. (2014) studied the seven best national sports training programs among the countries of Canada, France, Germany, Holland, Norway, Switzerland and New Zealand. In this study, it has been proved that the distance teaching of the curriculum is still in its initial phases, as indicated in Table 1. Only one of the seven countries (Canada) offers the entire curriculum as part of its distance-learning courses, the others countries or do not offer it or its virtuality is reserved just for support. 
Table 1. Seven best programs International Sport Technicians (Callary et al, 2014).

\begin{tabular}{|c|c|c|c|c|c|c|c|}
\hline & Canada & France & Germany & Holand & Norway & Switzerland & $\begin{array}{c}\text { New } \\
\text { Zealand }\end{array}$ \\
\hline $\begin{array}{l}\text { Distance } \\
\text { education }\end{array}$ & $\begin{array}{l}\text { It's offered } \\
\text { throughout } \\
\text { the country }\end{array}$ & $\begin{array}{c}\text { Part of the } \\
\text { program. There } \\
\text { is no alternative } \\
\text { to face-to-face } \\
\text { classes }\end{array}$ & $\begin{array}{c}\text { Not } \\
\text { offered }\end{array}$ & Not offered & $\begin{array}{l}\text { Not offered. } \\
\text { Technicians } \\
\text { can use Skype } \\
\text { in sessions if } \\
\text { they see ot } \\
\text { necessary. }\end{array}$ & $\begin{array}{l}\text { They have a } \\
\text { platform to } \\
\text { prepare the } \\
\text { modules or as } \\
\text { help after the } \\
\text { module. }\end{array}$ & Not offered \\
\hline
\end{tabular}

Denysova et al. (2018) provide for the introduction of methods to university education in physical education and sports. The use of platforms is compared with the use of the cloud. The advantages of the latter are concluded for both economic and technical reasons. In any case, the platforms present less quality in the programs and it is necessary to present a program with the use of ICTs for the improvement of interactivity (Veselovskaya, 2018).

The Spanish Educational Law of 2006 and the current LOMCE (2013) has been foreseen the possibility that a series of special education courses will be included as part of the formal educational system. Among them, we can find all the sports specialties. Within this study, we are approaching this educational innovation from the perspective of the training organized by the Spanish Federation of Skating (RFEP) for the teaching, at its different levels of sports technicians. This type of training contemplates distance, blended learning and faceto-face modality in their courses both for the entire course as well as in the different areas presented within it. Following Christensen et al. (2008), we would find ourselves in a disruptive innovation as it intends to open new possibilities for enrollment in courses by students that entail the use of new technologies as an element of change in conjunction (Sancho-Vinuesa et al., 2015) based on the MOOC programs in the university field.

The specific sports education of the RFEP are in transitory period pending of the final resolution by which the corresponding category will acquired the regulated status that other sports specialties have already achieved, such as soccer, basketball, athletics or diving (Dulsat \& Alvarez, 2019). With the exclusively federative qualifications, the title of coach obtained within this field of sports was only valid within the activities promoted by the different national or autonomic skating federations. The qualifications obtained thanks to the regulated teachings are on the same level as vocational trainings (FP): of middle grade for the first two courses and of a higher level with the third level (MECD, 2007).

The courses of the RFEP present in the areas of its curriculum a face-to-face mode blended learning and virtual ones; these last two with mandatory face-to-face tests according to the current legislation. To do this, the Moodle ${ }^{\infty}$ platform becomes a facilitator resource for the teaching and learning process. Despite the progressive incorporation of the use of virtual platforms, which facilitate autonomous communities with few practitioners to have trained technicians, it is also necessary to point out the difficulties in the form of resistance among their participants (Area \& Gonzalez, 2015) due to these changes in the teaching and innovation that they involve.

\section{THEORETICAL FRAMEWORK}

This study focuses on the individual resistances that students generate when they move to a new modality of virtual training (Caruth \& Caruth, 2013). These resistances are analyzed and interpreted in terms of their influence with the educational change they produce (Hargreaves et al., 1998; Fullan, 2002). In addition, the concept of resistance is understood as those consubstantial and vital actions (Vargas, 2012) to human nature, which proves its own existence and presents a systemic character (Anderson \& Stewart, 1988; Ferreter-iMora, 2009). It should be considered that the resistances fulfill a regulating and filter function guaranteeing the system's own stability (Garcia Aretio, 2002) and, with this, they should be considered as normal reactions, coming to believe it necessary to study them from the point of view of rejection towards the change that this training can cause (Rhoda, 2010). Likewise, we assume that any change entails the creation of some type of individual resistances (Nickerson, 2010). The change involves making an issue of the thought constituting 
the consolidation of the identity of individuals. Thereby, it is necessary to identify the rules that govern these changes (Popkewitz et al., 2003), as well as to face the resulting innovations.

The literature on the causes behind resistance is multiple and varied, from those that point to three major causes: consumption, product and channel as well as their interactions (Black et al., 2002) but with special attention to the two first (consumption and product) of innovation (Heinze et al., 2017). In this study, we will use the Theory of Resistance in Innovations (Ram \& Sheth, 1989) to be able to explore the sources of these resistances towards the formative change presented. This theory establishes two dimensions and five factors that influence the resistances: the Functional Dimension and the Psychological Dimension:

\section{FunctionaFactors}

The factors that influence the use of tools have been extensively detailed both at the level of not having used social networks and/or not understanding their use (Lin et al., 2012), as well as having had a negative experience with them (Chen $\&$ Hung, 2010) to even end up not knowing how to use communication tools (Hsu \& Lin, 2008). Otherwise, among the factors that directly influence the value of the product and its function, we have those related to the difficulty of using communication tools (Hsu \& Lin, 2008) due to the fact of experiencing difficulties in obtaining answers (Sun et al., 2012). Finally, regarding the factors associated with risks, we can find what is attributed to security issues (Bertot et al., 2012), legal disputes (Dunn, 2010) and the lack of confidence in technological applications (Chang \& Chuang, 2011).

\section{Psychological Factors}

Among the factors we find those associated with traditional beliefs such as, the fact of how knowledge is shared (Zhang et al., 2012) because they are potentially recriminated by other users (Wang \& Noe, 2010). Othrerwise, the factors that influence the image to a greater or lesser extent include the difficulty of being able to identify the benefits of sharing knowledge (Chiu et al, 2006), the fear of losing power (Wang \& Noe, 2010) and the fear of not being recognized at the community level (Sun et al., 2012).

The two dimensions and five factors of Ram and Sheth (1989) have been adapted into four categories for this study, focused on deepening the study of the individual resistances of the students. These four categories answered the following questions:

1. Contextual aspects characterized by sharing the information and presenting the levels of participation (Garcia, et al., 2011). This participation is related to the information given since it is considered that participation cannot be given without having informed of what is to be achieved first. Therefore, it is essential to ensure that communication is as effective as possible because only in a way the uncertainties of the changes can be removed (Fullan, 2002);

2. Users, as they can exert resistances, to a greater or lesser extent, on the training or organization based on trust as well as on the risks perceived (Chaouali et al., 2017; Robertson, 2016;), also violations are taken into account and the fact of receiving support from colleagues (Monereo, 2010);

3. Social Dimension (social norms); and, finally,

4. Attributes of technology (strictly functional elements, ie, connectivity and virtual platforms).

Studies using the Ram and Sheth model (1989) focus on the relationship of consumers with innovations, and they focus on the psychological component that these authors provide in their model. Thus, the main moment of resistance is in the initial stages due to the struggle for autonomy achieved so far and what can be lost by the innovations introduced (Garrido et al., 2018). Besides, it should be considered when innovation is introduced slowly and it becomes necessary to consider the relevance of the behavior in the decisions made and the resistance of consumers towards innovations although it is possible to model mental processing to get adopted the innovations (Claudy et al., 2015). It is possible to define that the strength of the attitude towards a habit is one of the perceptual and cognitive mechanisms found in resistance to innovation, and the change in attitude towards changes contributes to breaking those resistances. Hence, it is necessary for the consumer to obtain more information about innovation. It is essential to get an intentional behavior with which the consumer sets goals and strive to achieve them (Bagozzi, et al., 1999). In addition to studies 
related to consumers, we also find some studies focused on the use of mobile banking and the psychological barriers that Ram and Sheth (1989) establish.

The improvements are achieved when the resistances are overcome, being this an objective of both individual and innovative group. This will help us to improve the educational action, but at the same time, we should consider the resistances because the obstacles they pose are, in themselves, a source of improvement for all the participants (Garcia Aretio, 2003). This study presents the following objectives: first, to identify the categories that favor the resistances around this educational change; and, second, to propose possible improvements in the on-line courses with which improve the initial proposals related to the change in the instructional organization of these courses. In this way, the context will be specified, and emphasis will be placed on the existing resistances to the educational change as well as the training innovations as facilitators to the entrance and registration to the courses that the RFEP offers to the future sports technicians and superior sports technicians in the current latent period.

\section{METHOD}

This research follows a mixed approach with quantitative and qualitative methodology for a descriptive field research (Creswell, 2014) due to the direct collection of data from the chosen context and thanks to which the necessary information is obtained in order to determine the problem that may exist in the students' body with respect to the object being studied: distance training. The quantitative regarding the data relates the different categories to the field of change for students as well as qualitative in the analysis of the open responses of the questionnaires.

\section{Participants}

The context of this sample is the first course of Sports Technicians organized by the Royal Spanish Skating Federation in three different locations within the Spanish territory: Logrono, Madrid and Coruna. The data producing sample $\mathrm{N}=90$ students, belongs to a population of 223 students enrolled in the courses of which only 164 exceeded the theoretical part and could access the part of practical training during which the questionnaire is supplied through the course platform. Therefore, these students become the invited population for this study. In this way, it is achieved that the response rate of the students is of $54.88 \%$. It should be considered that for this group a $\mathrm{p}=0.75$ is obtained, with a margin of error of $3.4 \%$ for a confidence level of $95 \%$.

The socio-demographic characteristics of the students were: $53.46 \%$ females. For the age range, the students were among the following: 16-25 years (44.7\%), 26-35 years (32.7\%), 36-45 years (16.9\%), and 46-55 years (5.7\%). The students' origin for Autonomous Comunity were: $28.7 \%$ Galician, Andalucia 12.9\%, Basc Country 11.2\%, 10\% of Madrid, Catalonian 10\%, Valecian Community 6\%, Asturias 4.4\%, Castilian-Leon 4.4\%, Aragon 3.1\%, Navarra 3.1\%, Extremadura 3.1\%, and La Rioja 3.1\%. The students with distance training experience were: $43.4 \%$. To see the distribution according to the sports specialties in relation to the venues of the face-to-face courses see table 2 .

Table 2. Students approved in the course 2013-2014.

\begin{tabular}{cccccc}
\hline & Roller skate & In-line Roller & Artistic Skate & Speed Skate & Total \\
\hline Coruna & 19 & 0 & 39 & 0 & 58 \\
Logrono & 0 & 17 & 10 & 19 & 46 \\
Madrid & 13 & 0 & 26 & 21 & 60 \\
Total & 32 & 17 & 75 & 40 & 164 \\
\hline
\end{tabular}




\section{Data Collection and Analysis}

The instrument used is an online "ad-hoc" questionnaire with four categories. The items of the questionnaire use a descriptive numerical scale of 10 degrees, being the maximum value (1) and the minimum (10), and a second part of qualitative character for the responses on the individual resistances. The particularity of these items is their duality since the open question, of a qualitative nature, is crossed with the quantitative question where the individual resistance is linked to the concept of change.

\section{The Scale}

The instrument was validated by five judges chosen for their extensive experience in teaching within distance training. This determination is due to the fact of choosing distance training professionals with specific positions of direction, coordination or general management of courses of the same modality. The validation procedure was the same and the instrument was sent via e-mail and a framework for the criteria of uniqueness, relevance and importance of each of the items, as well as a section for observations.

The analysis of the answers was made using the statistical program SPSS-22 for the quantitative data and QSR-NVIVO 10 for the qualitative ones. The quantitative information was analyzed with the ANOVA to compare the average of more than one parametric group when they met the homoscedasticity test and the Wilcoxon W tests for two samples related to their medians in those cases when this was not fulfilled. The questionnaire of the students presents a level of reliability from the Cronbach alpha statistic of 0.836 as a whole.

\section{FINDINGS}

\section{Quantitative Analysis}

We present the degrees of the general acceptance of New Technologies as well as the data of Satisfaction of the course in relation to the data dependent on the field of change. In addition, they have been analyzed in terms of gender and experience in distance training (see Table 3). According to the degrees of acceptance of new technologies, we can observe values very close to one, an aspect that shows that students have a high acceptance of new technologies, as well as high level of satisfaction towards the course taken.

Table 3. Degrees of acceptance of new technologies and satisfaction

\begin{tabular}{cc}
\hline Degree & Average \\
\hline Acceptance of new technologies & 2.51 \\
Satisfaction & 3.81 \\
\hline
\end{tabular}

The quantitative data of the students (table 4) for the four categories show significant differences in the case of the group with experience in distance training as the categories related to new technologies and knowledge acquired are influenced by the change in the training modality while the students without distance training experience do not consider this aspect. We find significant differences in the category of psychological aspects that favor the overcoming of the difficulties as the students with greater degree of acceptance of the new technologies consider that they surpass the difficulties better than those that have less acceptance of the new technologies. 
Table 4. Student data analysis.

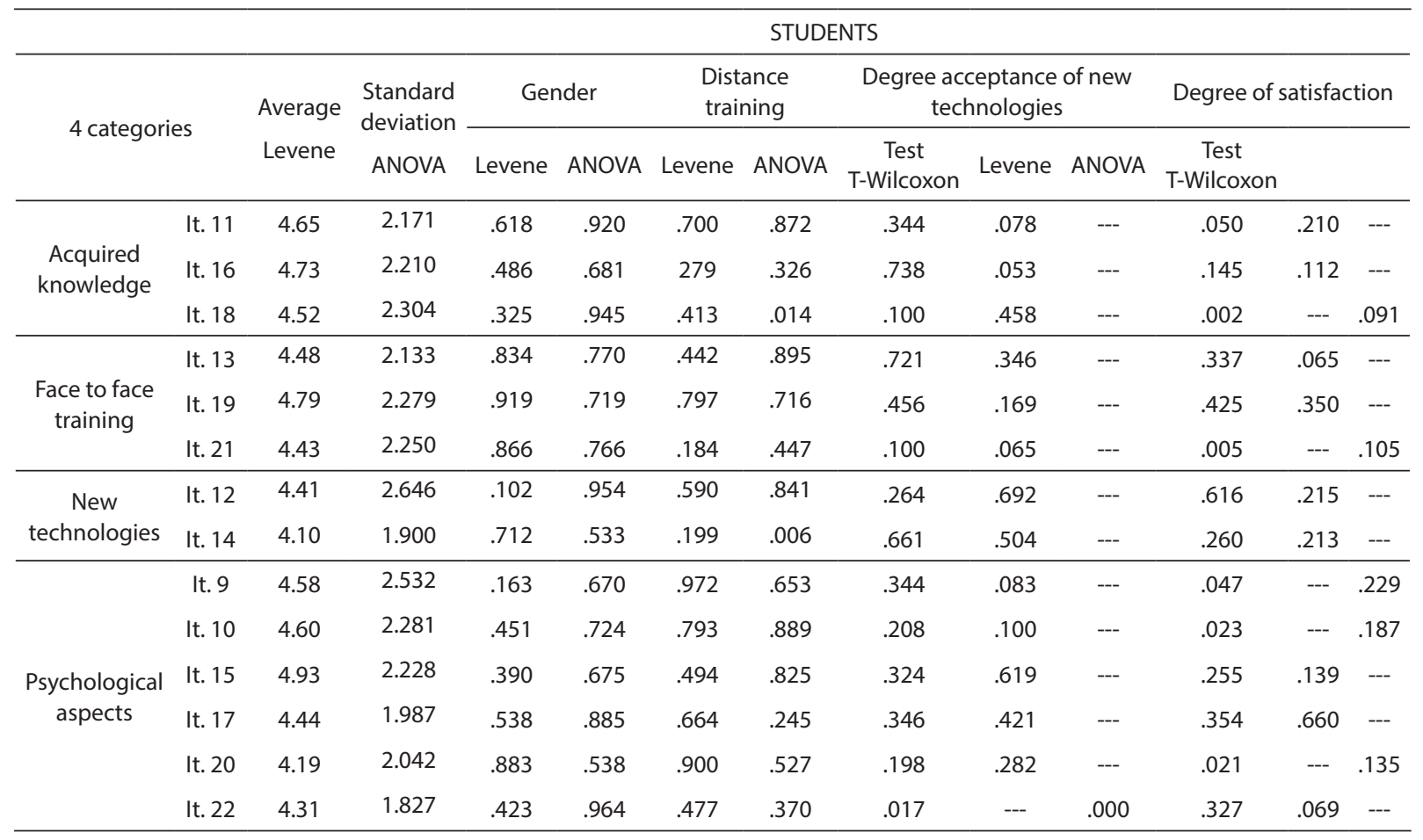

\section{Qualitative Analysis}

For the qualitative analysis, the data obtained in the open answer questions presented within the questionnaires of the students is examined by taking into account the following categories: Acquired Knowledge, Face-toFace Training, Psychological Aspects and New Technologies. Thanks to these results, what is intended is to approach the point of view of the students taking into account all the aspects they have learned as well as the differences between the two training modalities.

\section{Acquired Knowledge}

Students were asked how distance learning allows them to apply the knowledge acquired in their working places, how the same knowledge favors or harms training their learning pace and, finally, if they had applied what they have learned in their day to day as sports technicians. The group of participants taken as sample for this research has expressed that they have had the opportunity to apply the knowledge they have acquired: "I try to apply to myself every day what I learn and I find it interesting. I always give an opportunity to the new things that I learn and I also think that they can improve the training" (Student, 46). However, we can also find those who express the opposite, referring to the lack of training in the distance modality, resulting in an ineffective communication. The students affirm that with this training they are increasing their knowledge of how to conduct sessions and that the course allows them to apply the knowledge. Those who do not apply it, is due to not being working as sports technicians.

Regarding the learning rhythm of this distance training, the students respond with the denial of both positions, such as: "Neither harms nor favors" (Student, 75). However, they consider that it harms when there are missing face-to-face explanations or when doubts are not solved immediately. Most of the students mention a lack of adaptation that might facilitate the understanding of the functioning of this training modality. It should be noted that students feel overwhelmed during the first few days because they cannot understand how the platforms works as well as due to the amount of information: "As I was not used to distance learning at the beginning I felt a little bit lost" (Student, 33). To this difficulty should be added the timing, the schedule established to answer questionnaires and to carry out proposed activities because they consider that they do not have time to assimilate the contents before so many activities. 


\section{Face-to-face Training}

In this category students are asked about the lack of presence in contrast with the rest of the participants, as well as what they miss in this distance training. Regarding the lack of face-to-face training, the positioning of the students is ambiguous and the answers go in both directions: they see it right and wrong. However, in the second position, the justifications are related to the resolution of problems and the lack of explanations from the teaching staff. Moreover, positive elements have been included as the consideration that in a faceto-face course students might have to pay higher fees and that at the same time there is an investment of time and travel expenses that would pose difficulties to opt for it, such as: "Sometimes it is complicated to perform a distance course, but on the other hand, due to my working situation it is necessary to do it in this way in order to facilitate the development of the learning process" (Student, 87). The students miss more participation and communication, especially with the teaching staff.

The students recognize that, thanks to the distance learning method, they can immediately apply the acquired knowledge, as they do not have to neglect other aspects of their daily life. However, students request an increase of teaching hours in the face-to-face sessions, especially in those areas specific to sports specialties. In words of the students: "To be able to share more experiences with classmate and, in my case, there are issues that I have never dealt with and maybe directly explained would be easier for me to understand" (Student, 63). Without a doubt, the distance modality requires greater self-organization, therefore, a greater personal maturity and freedom of action is necessary.

\section{New Technologies}

In this category, two items are analyzed: the first one has been already presented in the quantitative analysis section and the second one refers to the opinion that the use of the platform deserves. The students consider that the use of the platform is difficult, especially during the first days, as in the following case: "There were things that I could not find. It's a matter of getting to know the platform and then its functioning starts to be easier" (Student, 13). This difficulty is placed in several aspects as in the organization of information or in personal issues of ignorance and in the lack of practice, being both centers of which the following response can be highlighted: "It gets more difficult depending on the moments, but it has always been positive. I have only had some problems with some documents and with the deadlines" (Student, 7). Although they had also highlighted those answers that place the difficulties in external factors of the course, such as connection speed and little connectivity.

\section{Psychological Aspects}

In this category we find questions which are specific for each individual and how these aspects may affect their academic performance, responding to the degree of satisfaction of the course and also what is expected from them. For students the questions previously mentioned are focused on the needs and satisfactions during the course, their personal motivations as well as the difficulties encountered. The students place the needs and satisfactions of the course as a positive aspect for their future work. For this reason, there is a close link between the responses of students based on getting the title as well as the knowledge acquired, an aspect that favors motivation and interest, as it can be seen in the following quotation from a student: "To train in my sport to improve my knowledge and be able continue teaching my students" (Student, 19).

In this category, we also find answers related to the need to know the teaching staff better as well as to interact with peers. On the other hand, they are also interested in the contents of those areas that have an almost immediate application. Regarding the difficulties, the students consider that they must overcome personal aspects such as effort, self-organization and the availability of time. The areas that most interest them are those that present the greatest difficulties, either due to the extension of the contents or because they demand a high effort from the students. 


\section{DISCUSSIONS}

The category of Acquired Knowledge is not a reason to generate individual resistances, since the students reach the expectations and needs of the course, although there are significant differences between those with distance training experience and those without it. The students who currently do not work as sports coaches answer that they find it difficult to know if they can apply the knowledge acquired. However, they maintain a high degree of satisfaction with the course (Navimipour \& Zareie, 2015).

For students, the learning pace is slower than they would like during the first weeks and this aspect could be considered a generator of resistance for this course modality (Chen \& Tat, 2016). This coincides with the barriers to innovation in the individual environment during the implementation phase, and the difficult problems that individuals find (Oumlil \& Juiz, 2016). To the above mentioned, we must add the slowness, the timing, the period established to answer questionnaires and the realization of the proposed activities, since students consider that they do not have enough time to assimilate the contents due to the number of areas and training activities.

Another element generating resistances that initially has not been contemplated would be the communication between the participants during the course. Although communication must also be considered as a fundamental element in achieving the implementation of the changes during this previous period (Ferrer, 2015), because innovation and changes in education obtain values of $46.3 \%$ where what is new, is better than what is "has changed. Moreover, you get an increase in the consideration of innovation by making it visible, by communicating from different means the changes that are carried out (Semova et al., 2015). This aspect coincides with the studies of Gutierrez et al. (2016) which conclude that in order to minimize obstacles communication should be a priority for those teachers who are committed to the quality of virtual instruction, as well as the study by Kumar \& Owston (2016) where the students initial evaluation regarding new technologies is relevant to reduce subsequent barriers.

Within the category, "Face-to-face training", it is highlighted the lack of communication with the other groups of participants - coordination and teaching staff -. At the same time, other advantages besides are perceived such as the low cost that this training requires (Barbera et al., 2016, Jacob \& Radhai, 2016). The contribution of audiovisual media also should be taken into account, above all, as the student considers that they are not used largely, although Yilmaz \& Keser (2016) assure that their use does not provide benefits for learning while the activities with meaningful learning do. Another possibility is to approach the proposal of Reyes, Jimenez \& Soto (2016), where one should provide flexible content and adapt them to the individual needs of each student.

Resistances related to psychological aspects are generated in those cases in which initial expectations are not met. Among the most commented expectations, we can find the obtaining of an official certificate (Barbera et al., 2016). Furthermore, the perception of acquiring little knowledge on the part of the students generates resistances because it would be a minimum use of the course and, to avoid this, teachers can contribute motivating the students (Liaw \& Huang, 2013) by providing elements of interaction in this formative modality (discussion forums and assignment of tasks), improving the intrinsic motivation in relation to their perceived satisfaction, as well as the extrinsic motivation understood as utility (Gutierrez et al., 2016). Regarding satisfaction, it coincides with the significance of the relationship between students and contents as a predictor of satisfaction (Kuo et al., 2014). Finally, within these psychological aspects, an element could contribute to the reduction of resistances. This element is the official recognition of the course as well as its recognition beyond the federative scope of the certificate obtained, since it prepares the students to enter the workplace.

Finally, the participants consider New Technologies category as a good tool, although they also believe that it would be necessary to apply some improvements, such as the incorporation of videos, videoconferences or other forms of synchronic communication (Luran et al., 2015). Additionally, this perceived utility is essential to predict the intention of using mobile technologies where teaching practice is perceived as a profession where the changes in day to day need to be considered, and there is a certain resistance to the use of mobile technologies, because they are digital natives, and when they live with them as entertainment; they do not know how to look at the educational side (Sanchez et al., 2017). In general, resistances could be generated both by its complicated beginning and by the use and management of the platform. Although, 
as Nova et al. (2017), the digital divide in ICT users is based on the knowledge, they have of ICT and not on the difficulties in accessing the same, and they are perceived difficulties in the use of ICTs due to lack of resources pedagogical that is required for its implementation. Resistance to the use of new technologies among teachers is among other issues may be related to the lack of training they present, although the teacher himself expresses lack of time to be able to train (Mercader, 2019).

\section{CONCLUSIONS}

The objective of this study has been twofold: Firstly, we set out to identify those aspects and/or categories that foster resistances and that are related to educational change; a more than significant aspect in the case of students with previous experience in distance training both for the acquisition of knowledge and for the use of new technologies. This is because these students are able to take more advantage of the contents acquired in their sports practice and, on the other hand, because the distance training experience gives students advantages when using the online platform of the course. In relation to the aforementioned, the students with the highest degree of acceptance of the new technologies solve much better the problems that have arisen during the course.

Thus, the categories related to New Technologies and Acquired Knowledge have an important weight in relation to educational change. It should be noted that there are significant differences in the category of Psychological Aspects. These differences are related to the degree of acceptance of new technologies by students, being these the reason why the other psychological factors are susceptible to another variable that should be studied in those cases in which there is a change in the training modality.

The second objective: "Propose possible improvements in the online courses with which to correct the initial proposals of the change in the instructional organization of the courses," for which we highlight the following improvement: pose the figure of the tutor as a catalyst for the training of the students and as facilitator of the use and understanding of the platform. This figure could be one per course hosting a maximum of 30 students. Its first function would be to address the new enrolled students and explain everything that will be found on the platform and how the contents and the different tools are organized. A second proposal would be related to communication between students and teachers using tools present on the platform such as chats, forums or other synchronous and immediate communication tools since that is what the students think is needed. It is necessary to introduce Vila's proposal (2014) that, in order to reduce obstacles to innovation, it advises to raise awareness and raise awareness among the leaders and people in charge of the courses, as well as to establish internal collaborations with teachers and other professionals close to the courses as intense work with the public administrations and official bodies. This could be accompanied by sustaining changes and innovation over time, while reviewing and updating the methods of teaching and assessment, changes that require cooperation between the professionals involved and sharing of knowledge, this leads to the establishment of learning communities (Liesa et al., 2018).

\section{BIODATA and CONTACT ADDRESSES of AUTHORS}

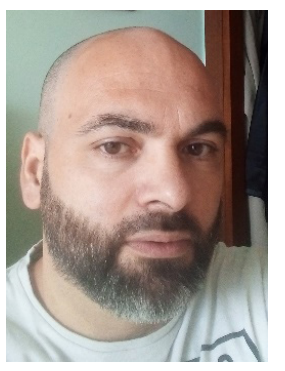

Dr. Carles DULSAT is an Assistant Professor at the Isabel I University since 2017. Dr. Dulsat gained his Ph.D. in Education at December 2015. His academic interest areas are e-learning, open and distance learning, teaching and learning at sport technicians and use of internet in education; pre-service teachers; and, teach and learn natural science at childhood education. He has over than 4 journal articles published in international indexes, 2 international book chapters and others papers submitted to international meetings.

Carles DULSAT

Faculty of Humanities and Social Science

Address: Universidad Isabel I, 09003, Burgos, Spain

Phone: +0034 629196371,

E-mail: carlos.dulsat@uil.es 


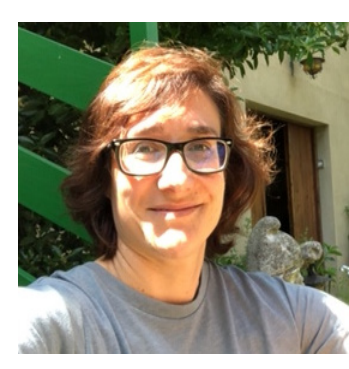

Dr. Isabel ALVAREZ is an Associate Professor at the Autonomous University of Barcelona since 2005. Dr. Alvarez gained her Ph.D. in Educational Technology at the University of Barcelona. She teaches Professional Education subjects in the Teacher Educaton Program. Her academic interest areas are social network analysis, open and distance learning, pre-service teachers, e-learning, cyber behaviors and use of internet in education. She has several journal articles published in international indexes, international book chapters and other national and international articles, papers submitted to international meetings.

\section{Isabel ALVAREZ}

Department of Social and Systematic Pedagogy, Faculty of Education

Address: Autonomous University of Barcelona, 08193, Bellaterra, San Cugat del Valles, Spain

Phone: +345811411

E-mail: isabel.alvarez@uab.cat

\section{REFERENCES}

Anderson, C. M. \& Stewart, S. (1988). Para dominar la resistencia. Guia practica de terapia familiar. Buenos Aires: Amorrortu editores.

Area, M. \& Gonzalez, C. S. (2015). De la ensenanza con libros de texto al aprendizaje en espacios online gamificados. Educatio Siglo XXI, 33(3), 15-38. http://dx.doi.org/10.6018/j/240791

Bagozzi, R. P. \& Lee, K. H. (1999). Consumer resistance to, and acceptance of, innovations. Advances in Consumer Research, 26, 218-225. http://acrwebsite.org/volumes/7902/volumes/v26/NA-26

Barbera, E., Gomez, P. \& Fernandez, F. (2016). A cross-national study of teacher's perceptions of online learning success. Open Learning: The Journal of Open, Distance and e-learning, 31(1), 25-41. http:// dx.doi.org/10.1080/02680513.2016.1151350

Bertot, J., Jaeger, P. \& Hansen, D. (2012). The impact of polices on government social media usage: Issues, challenges, and recommendations. Government Information Quarterly, 29(1), 30-40. http://dx.doi. org/10.1016/j.giq.2011.04.004.

Black, N., Lockett, A., Ennew, C., Winklhofer, H. \& McKechnie, S. (2002). Modelling consumer choice of distribution channels: an illustration from financial services. International Journal Of Bank Marketing, 20(4), 161-173. http://dx.doi.org/10.1108/02652320210432945

Bozkurt, A. (2019). Intellectual roots of distance education: a progressive knowledge domain analysis. Distance Education, 40(4), 497-514. https://doi.org/10.1080/01587919.2019.1681894

Callary, B., Culver, D., Werthner, P. \& Bales, J. (2014). An Overview of Seven National High Performance Coach Education Programs. International Sport Coaching Journal, 1(3), 152-164. http://dx.doi. org/10.1123/iscj.2014-0094

Caruth, G. D \& Caruth, D. L. (2013). Understanding resistance to change: A challenge for Universities. Turkish Online Journal of Distance Education, 14(2), 12-21. http://tojde.anadolu.edu.tr

Chang, H. \& Chuang, S. (2011). Social capital and individual motivations on knowledge sharing: Participant involvement as a moderator. Information \& Management, 48(1), 9-18. http://dx.doi. org/10.1016/j.im.2010.11.001

Chaouali, W., Souiden, N. \& Ladhari, R. (2017). Explaining adoption of mobile banking with the theory of trying, general self-confidence and cynicism. Journal of Retailing and Consumer Services, 35, 57-67. http://dx.doi.org/10.1016/j.retconser.2016.11.009

Chen, C. \& Hung, S. (2010). To give or to receive? Factors influencing members' knowledge sharing and community promotion in professional virtual communities. Information \& Management, 47(4), 226-236. http://dx.doi.org/10.1016/j.im.2010.03.001 
Chen, W. S. \& Tat, A. Y. (2016). An empirical evaluation of critical factors influencing learner satisfaction in blended learning: a pilot study. Universal Journal of Educational Research, 4(7), 1667-1671. http:// dx.doi.org/10.13189/ujer.2016.040719

Christensen, C., Johnson, C. W. \& Horn, M. B. (2008). Disrupting Class: How Disruptive Innovation Will Change the Way the World Learns. New York: Mc Graw Hill.

Claudy, M. C., Garcia, R., \& O’Driscoll, A. (2015). Consumer Resistance to Innovation -a behavioral reasoning perspective. Journal of the Academy of Marketing Science, 43(4), 528-544. https://doi. org/10.1007/s11747-014-0399-0

Creswell, J. (2014). Research design. Qualitative, Quantitative and Mixed Methods approaches. Thousand Oaks, California: SAGE Publications.

Denysova, L., Skynkawk, O. \& Usychenko, V. (2018). Cloud technologies in distance learning of specialists in physical culture and sports. Journal of Physical Education and Sport, 18(1), 469-472. https://doi. org/10.7752/jpes.2018.s166

Dulsat, C. \&Alvarez, I. (2018). Lessons learned froma distance course: "more use could have been be made of it". Universal Journal of Educational Research, 6(9), 1921-1927. https://doi.org/10.13189/ ujer.2018.060910

Dulsat, C. \& Alvarez, I. (july de 2019). Change modality: face to vitual for a course of Spanish Skate Federation: difficulties and opportunities for its implementation. In: Ch. A. Shoniregun (president), World Congress on Education, Dún Laoghaire, Irlanda, july, $16^{\text {th }}-18^{\text {th }}$.

Ferrer, R. M. (2015). La influencia del factor humano, el liderazgo y la cultura de las organizaciones, Revista Internacional de Investigacion en Ciencias Sociales, 11(1), 102-114. http://dx.doi.org/10.18004/ riics.2015.julio.102-114

Ferreter i Mora, J. (2009). Resistencia. A Diccionario de filosofia, 4, 3079-3081. Barcelona: editorial Ariel.

Fullan, M. (2002). Las fuerzas del cambio. Explorando las profundidades de la reforma educativa. Madrid: Akal Ediciones.

Garcia Aretio, L. (2002). Resistencia, cambios y buenas practicas en la nueva educacion a distancia. RIED, Revista Iberoamericana de educacion a distancia, 5(2), 9-35.

Garcia Aretio, L. (2003). Innovacion y resistencias. Recuperado de http://e-spacio.uned.es/fez/eserv/ bibliuned:20127/innovacion.pdf

Garcia, A. M., Alamo, F. R. \& Garcia, F. (2011). Antecedentes de la resistencia al cambio: factores individuales y contextuales. Cuadernos de Economia y Direccion de la Empresa, (14), 231-246. http://dx.doi. org/10.1016/j.cede.2011.02.007

Garrido, S. M, Thomas, H. E. \& Becerra, L. D. (2018). Tecnologia, ideologia y hegemonia. Repensando los procesos de resistencia socio-tecnica. Ciencia, Docencia y Tecnologia, 29(56), 186-207. http://www. pcient.uner.edu.ar/cdyt/article/view/377/338

Gutierrez, E., Gallego, M. J. \& Simone, A. (2016). Barriers in computer-mediated communication: typology and evolution over time. Journal of e-learning and Knowledge Society, 12(1), 107-119.

Hargreaves, A., Earl, L. \& Ryan, J. (1998). Una educacion para el cambio. Barcelona: editorial Octaedro.

Heinze, J., Thomann, M., \& Fischer, P. (2017). Ladders to m-commerce resistance: A qualitative meansend approach. Computers in Human Behavior, 73, 362-374. http://dx.doi.org/10.1016/j. chb.2017.03.059

Hsu, C., \& Lin, J. (2008). Acceptance of blog usage: The roles of technology acceptance, social influence and knowledge sharing motivation. Information \& Management, 45(1), 65-74. http://dx.doi. org/10.1016/j.im.2007.11.001

Jacob, S. \& Radhai, S. (2016). Trends in ICT E-learning: Challenges and Expectations. International Journal of Innovative Research \& Development, 5(2), 196-201. http://www.i-scholar.in/index.php/IJIRD/ issue/view/14394 
Kumar, K. L. \& Owston, R. (2016). Evaluating e-learning accessibility by automated and student-centered methods. Education Tech Research Development, 64(2), 263-283. http://dx.doi.org/10.1007/ s11423-015-9413-6

Kuo, Y. C., Walker, A. E., Schroder, E. E. \& Belland, B. R. (2014). Interaction, internet self-efficacy and selfregulated learning as predictors of student satisfaction in online education courses. The Internet and Higher Education, 20, 35-50. http://dx.doi.org/10.1016/j.iheduc.2013.10.001

Liaw, S. S. \& Huang, H. M. (2013). Perceived satisfaction, perceived usefulness and interactive learning environments as predictors to self-regulation in e-learning environments. Computers \& Education, 60(1), 14-24. http://dx.doi.org/10.1016/j.compedu.2012.07.015

Liesa, E., Castello, M. \& Becerril, L. (2018). Nueva escuela, ¿nuevos aprendizajes? Revista de Estudios y Experiencias en Educacion, 2(1), 15-29. https://doi.org/10.21703/rexe.Especial2_201815291

Lin, C., Wu, J., \& Yen, D. (2012). Exploring barriers to knowledge flow at different knowledge management maturity stages. Information \& Management, 49(1), 10-23. http://dx.doi.org/10.1016/j. im.2011.11.001

Luran, A. S., Buenahora, M. L. \& Vargas, C. C. (2015). Perspectiva del aprendizaje tradicional y del aprendizaje con comunicacion bidireccional en actividades educativas. Revista de Investigaciones UNAD, 14(1), 253-262. http://dx.doi.org/10.22490/25391887.1468

MECD (2007). Real Decreto 1363/2007. Madrid, Ministerio de Educacion, Cultura y Deporte. Disponible en: http://www.boe.es/boe/dias/2007/11/08/pdfs/A45945-45960.pdf

Mercader, C. (2019). Las resistencias del profesorado universitario a la utilizacion de las tecnologias digitales. Aula Abierta, 48(2), 167-174. https://doi.org/10.17811/rifie.48.2.2019.167-174

Monereo, C. (2010). ¡Saquen el libro de texto! Resistencia, obstaculos y alternativas en la formacion de los docentes para el cambio educativo. Revista de Educacion, 352, 583-597. http://www. revistaeducacion.educacion.es/re352/re352_26.pdf

Navimipour, N. J. \& Zareie, B. (2015). A model for assessing the impact of -learning systems on employees' satisfaction. Computers in human Behavior, 53, 475-485. http://dx.doi.org/10.1016/j. chb.2015.07.026

Nickerson, J. (2010). Leading change in a Web 2.1 world (1st ed.). Washington, D.C.: Brookings Institution Press.

Nova, I. Aleman, L. Y. \& Gomez, M. G. (2017). Alfabetizacion Socio-Digital y Pedagogia constructivista para superar la Brecha-Digital. ENSAYOS, Revista de la Facultad de Educacion de Albacete, 32(1), 33-47. http://www.revista.uclm.es/index.php/ensayos

Oumlil, R. \& Juiz, C. (2016). An Up-to-datesurvey in Barriers to Open Innovation, Journal of Technology, Management \& Innovation, 11(3), 137-152. https://doi.org/10.4067/S0718-27242016000300016

Perez, B. E. (2017). Cursos masivos abiertos en linea, MOOC. Un analisis pedagogico. In: J. M. Anton (Gen. Sec.) XVIII Encuentro Internacional Virtual Educa, Bogota, Colombia, june, 13th-16th.

Popkewiz, T. S., Franklin, B. \& Pereyra, M. (2003). Historia cultural y educacion: ensayos criticos sobre conocimiento y escolarizacion. Barcelona: Ediciones Pomares.

Ram, S. \& Sheth, J. (1989). Consumer Resistance to Innovations: The Marketing Problem and its solutions. Journal of Consumer Marketing, 6(2), 5-14. http://dx.doi.org/10.1108/EUM0000000002542

Reyes, A., Jimenez, J. \& Soto, D. E. (2016). Personalizacion de contenidos en t-learning a traves de Universal Design for Learning (UDL). 14th LACCEI International Multi-Conference for Engineering, Education and Technology: "Engineering Innovations for Global Sustainability". 20-22 july 2016, San Jose, Costa Rica.

Rhoda, J. (2010). Individual resistance to IT innovations. Communications of the ACM, 53(4), 144. http:// dx.doi.org/10.1145/1721654.172169 
Robertson, N., McDonald, H., Leckie, C. \& McQuilken, L. (2016). Examining customer evaluations across different self-service technologies. Journal of Services Marketing, 30(1), 88-102. http://dx.doi. org/10.1108/JSM-07-2014-0263

Sanchez, J. C., Olmos, S. \& Garcia, F. J. (2017). Motivacion e innovacion: aceptacion de tecnologias moviles en los maestros en formacion. RIED. Revista Iberoamericana de Educacion a Distancia, 20(2), 273292. http://dx.doi.org/10.5944/ried.20.2.17700

Sancho Vinuesa, T., Oliver, M. \& Gisbert, M. (2015). MOOCS en Cataluna: un instrumento para la innovacion en educacion superior. Educatio XXI, 18(2), 125-146. http://dx.doi.org/10.5944/ educXXI.13462

Semova, D. J., Aladro, E., Requeijo, P. Segovia, A.I. \& Padilla, G. (2015). Innovacion en la ensenanza universitaria a traves de redes colaborativas: caso de estudio aplicado al grado de periodismo, Profesorado, Revista de curriculum y formacion del profesorado, 19(3), 361-379. http://www.ugr.es/ local/recfpro/rev193COL1.pdf

Vargas, J. (2012). A proposito de la Resistencia como propuesta teorica del estudio historico. Tiempo y Espacio, 28, 7-22. Recuperado de: http://www.ubiobio.cl/miweb/webfile/media/222/ Tiempo/2012/\%2328.01.pdf

Veselovskaya, J. A., Sidorova, N. V., Kuzina, N. G. \& Stolyarova, I. V. (2018). Interactive distance education technologies: physical education and sports educational process quality analysis. Theory and Practice of Physical Culture, 2, 12-14. http://www.teoriya.ru/en/node/7942

Villa, A. (2014). La innovacion social en el ambito universitario, Revista Argentina de Educacion Superior, 8, 188-210. http://www.revistaraes.net/revistas/raes8_art9.pdf

Wang, S. \& Noe, R. (2010). Knowledge sharing: A review and directions for future research. Human Resource Management Review, 20(2), 115-131. http://dx.doi.org/10.1016/j.hrmr.2009.10.001

Yilmaz, F. G. K. \& Keser, H. (2016). The impact of reflective thinking activities in e-learning: a critical review of the empirical research. Computers \& Education, 95, 163-173. http://dx.doi.org/10.1016/j. compedu.2016.01.006

Zhang, Y., Fang, Y., Wei, K. \& Chen, H. (2010). Exploring the role of psychological safety in promoting the intention to continue sharing knowledge in virtual communities. International Journal of Information Management, 30(5), 425-436. http://dx.doi.org/10.1016/j.ijinfomgt.2010.02.003 